\title{
New insights from recently migrated CROP multichannel seismic data at the outermost Calabrian arc accretionary wedge (Ionian sea)
}

\author{
Vera VALEnti (*)
}

\section{ABSTRACT}

This study addresses selected aspects of the stratigraphic-structural setting of the outermost Calabrian Arc accretionary wedge and underlines relationships between structural development and Messinian evaporite stratigraphy through the analysis of re-processed CROP multichannel seismic reflection profiles.

A detailed seismostratigraphic analysis, calibrated with P-velocities compiled by previous works, images a general bipartition of the Messinian evaporite deposits: the transparent "lower subunit» appears to have undergone ductile-flow deformation», with the development of salt-cored thrusting structures, and the layered «upper subunit» appears to be characterized by brittle deformation. The difference in both the seismic facies and the deformational style imaged for the Messinian evaporite unit allows a better defined unit stratigraphy that consists of a salt layer below and a gypsum and marl layer above.

Lateral variations in composition and/or thickness of the Messinian evaporites are the local cause of the replacement of the transparent and layered subunits with a more chaotic facies as well as a change in the deformation style, with the development of doubleverging imbricated thrust sheets of the whole Messinian sequence.

Most of the accreted outermost accretionary wedge is imaged to have resulted from the progressive piling up and associated thrusting of the Messinian evaporites and overlying Plio-Quaternary sediments; the gently dipping-reflector located at the base of the Messinian evaporites shows negative polarity at some places, suggesting that it acts as the décollement level.

Active deformation occurs on the outermost accretionary wedge as related to subduction-driven shortening; further on, near-surface gravitational slide tectonics is imaged as related to a growing outermost wedge and favoured by the salt tectonics and/or to fluid overpressuring on the décollement level.

KEY WORDS: Seismic reflection data, accretionary wedge, Messinian deposits.

\section{INTRODUCTION}

Tectonic sedimentary accretion is a well-established geological process at active continental margins. Here, offscraping, progressive deformation and piling up of deep-sea sediments concur to form a sequence of several imbricate thrust sheets of the accretionary wedge.

As the wedge construction processes are strongly influenced by both the dip of the basal décollement level and its mechanical characteristics (as described by the "Coulomb wedge» theory, DAvIs et alii, 1983), a detailed study of the deformation front could provide a good source of information for understanding the wedge's evolution and mechanics.

(*) Dipartimento di Geologia e Geodesia, via Archirafi, 20 90100 Palermo. E-mail address: valv@unipa.it
The Calabrian Arc accretionary wedge was formed by the convergence of the African and European regions and the subduction of the Ionian plate beneath Calabria: sediments have been offscraped from the subducting Ionian plate and piled up along thrust faults opposite the European region.

However, it is an unique accretionary wedge showing, unusually, both a low décollement dip and a narrow taper (Lenci \& Doglioni, 2007; Minelli \& FACCENNA, 2010) and the highest outward growth rate of its deformation front (TORELLI et alii, 2007), perhaps reflecting the occurrence of Messinian salt within the wedge (e.g. PolONIA et alii, 2008).

Although regional geophysical studies conducted over the past 20 years suggest constraints on the internal structure of the Calabrian Arc accretionary wedge (e.g. CATALANO \& SULLI, 2006), few, if any, of these studies have discussed, in detail, its thin frontal portion, i.e. the transition of the accretionary wedge to the Ionian abyssal plain. I believe that this is the reason why two major questions remain unanswered: 1) are the Messinian evaporites composed of salt that makes them behave as a weak décollement level? 2) how do the occurring Messinian evaporites influence the tectonic style and geometry of the wedge?

Until now, the seismic character of the Messinian evaporites, in terms of reflectivity patterns and deformational structures, has not yet been convincingly related to their stratigraphic layering and rheology. That is because the rough seabed topography (otherwise known as the "cobblestone topography», HERSEY, 1965) at the outermost accretionary wedge and the occurrence, at depth, of diffraction hyperbolae coming from the Messinian evaporitic sequence have strongly hampered the study of the outermost wedge's internal structure.

The afore-mentioned questions are addressed here through the analysis of a recently-migrated set of existing multichannel seismic reflection profiles from the Ionian Sea around the front of the wedge, to the east and southeast of the Malta Escarpment (fig. 1). A new detailed seismostratigraphic analysis allows a better definition of the seismic stratigraphy of the Messinian evaporite deposits.

The style of deformation at the wedge front in different transects is analyzed, and the role played by the Messinian evaporites in controlling the tectonic style of the thin frontal portion of the wedge is discussed.

\section{REGIONAL SETTING}

The study area is located in the Ionian Sea facing the eastern Sicily-Calabria offshore and the Ionian abyssal plain (fig. 1). Several authors have proposed a convergent 


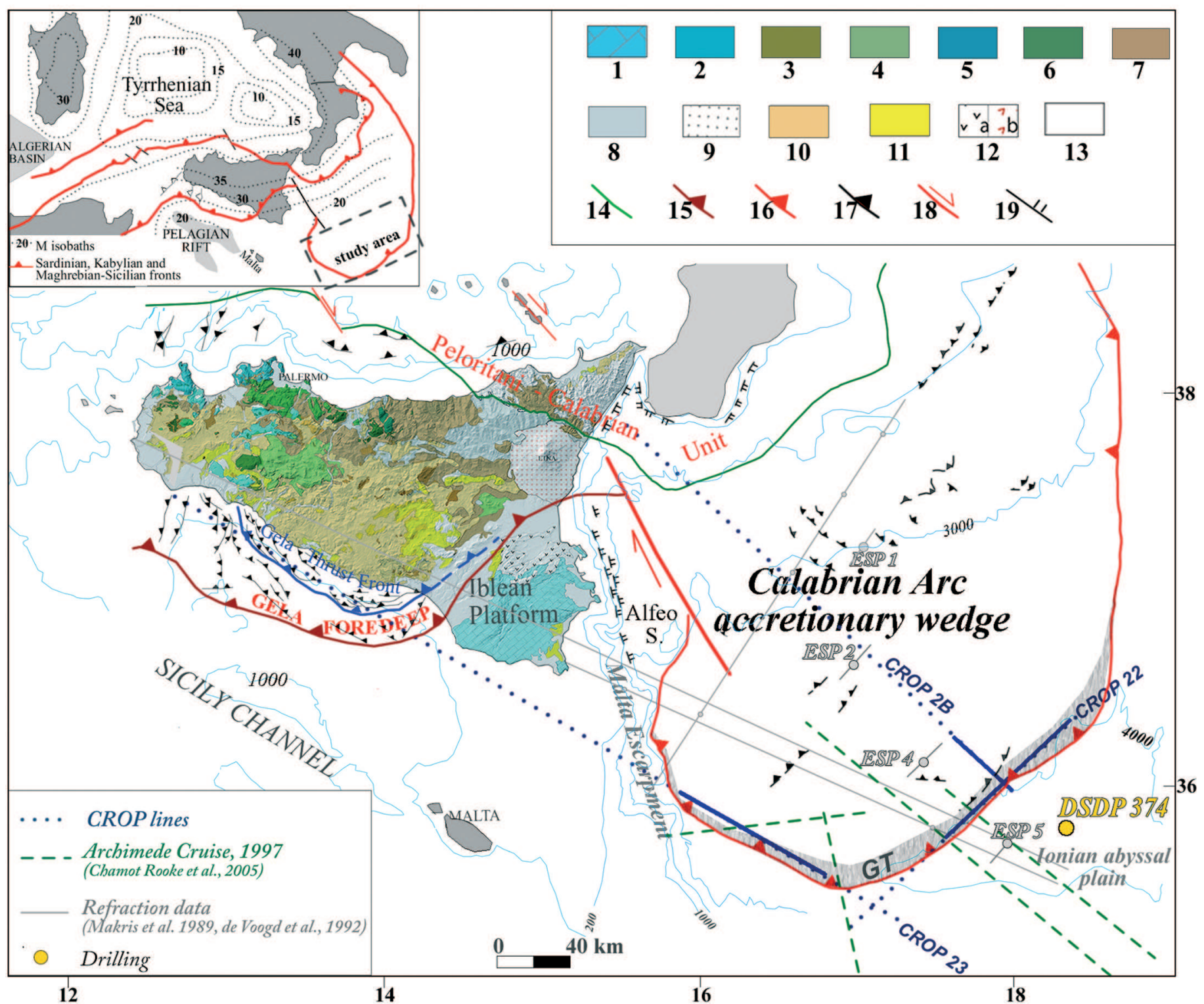

Fig. 1 - Structural map of the study area (modified from CATALANO et alii, 2010). The grid of the interpreted (CROP) multichannel seismic profiles (bold segments), together with the location of seismic reflection lines, seismic refraction profiles and drilling that contribute to seismic interpretation proposed in this paper, is shown. GT: Gravitational tectonics. The numbers in the legend are: 1) Iblean units; 2) shelf to pelagic carbonate (Trapanese-Saccense) units; 3) shelf to deep-water carbonate (Monte Genuardo) units; 4) deep-water carbonate (Sicanian) units; 5) shelf carbonate (Panormide) units; 6) slope to deep-water (Imerese-Panormide) units; 7) Miocene Flyschs; 8) Sicilide units; 9) CalabrianPeloritani units; 10) Miocene-Pliocene syntectonic deposits; 11) Plio-Pleistocene syntectonic deposits; 12) Plio-Quaternary volcanic rocks; 13) Pleistocene deposits; 14) Fossilized southern margin of the Calabrian units; 15) Maghrebian-Sicilian thrust front; 16) Calabrian Arc accretionary wedge thrust front; 17) thrusts; 18) faults with strike-slip component; 19) extensional faults. Structural features in broken line are from BIGI et alii, 1992. Inset shows a schematic structural map of the study and surrounding area.

geodynamic setting regarding this area, assuming an Ionian lithosphere subducting beneath Calabria to the northwest (e.g. CAPUTO et alii, 1970), and beneath Greece to the east (e.g. LE Pichon \& ANGELIER, 1979).

Deep reflection seismic lines clearly image a flexure of the Ionian lithosphere beneath Calabria (FINETTI, 1982, 2005; CERNOBORI et alii, 1996; CATAlANo \& Sulli, 2006; Minelli \& FaCCENNA, 2010), continuing in a seismogenic NW- more than $70^{\circ}$-dipping slab (GASPARINI et alii, 1982) that extends down to some $500 \mathrm{~km}$ beneath the SE Tyrrhenian basin, as demonstrated by the mantle tomography (SElvagGi, 2001; Piromallo \&
Morelli, 2003; FACCEnNA et alii, 2004). The high angle of the subduction along the Benioff plane, in the SE Tyrrhenian Sea, has been mainly ascribed to the slab pull of a retreating, old and dense oceanic lithosphere (MALINVERNO \& RYAN, 1986; Doglioni et alii, 1999; ROSENBAUM \& LISTER, 2004).

The NW-dipping Benioff plane abruptly disappears laterally beneath the Southern Apennines and Sicily (e.g. GASPARINI et alii, 1982), where the occurrence of a «subducting continental lithosphere» (ROURE et alii, 1990) causes a well-developed collisional complex (CATALANO et alii, 2000). The arcuate shape of the Apenninic front also 
ERROR: undefined

OFFENDING COMMAND: get

STACK :

10

-dictionary1 